\title{
Arcobacter mytili sp. nov., an indoxyl acetate- hydrolysis-negative bacterium isolated from mussels
}

\author{
Luis Collado, ${ }^{1}$ Ilse Cleenwerck, ${ }^{2}$ Stefanie Van Trappen, ${ }^{2}$ Paul De Vos ${ }^{2}$ \\ and Maria Jose Figueras ${ }^{1}$
}

Correspondence

Maria Jose Figueras

mariajose.figueras@urv.cat

\author{
${ }^{1}$ Unitat de Microbiologia, Departament de Ciències Mèdiques Bàsiques, Facultat de Medicina i \\ Ciències de la Salut, IISPV, Universitat Rovira i Virgili, Sant Llorenç 21, 43201 Reus, Spain \\ ${ }^{2}$ BCCM/LMG Bacteria Collection and Laboratory of Microbiology, Faculty of Sciences, Ghent \\ University, K. L. Ledeganckstraat 35, 9000 Ghent, Belgium
}

\begin{abstract}
Three Arcobacter isolates, recovered from mussels (genus Mytilus), and one isolate from brackish water in Catalonia (north-east Spain) showed a novel pattern using a recently described identification method for members of the genus Arcobacter, 16S rRNA gene RFLP.

Enterobacterial repetitive intergenic consensus PCR fingerprinting demonstrated that the three isolates from mussels belonged to two genotypes and that the fourth isolate from water belonged to a third genotype. Analysis of the $16 \mathrm{~S}$ rRNA and rpoB gene sequences showed that the new isolates formed a separate lineage within the genus Arcobacter. This was also confirmed by the low DNA-DNA relatedness values (16-30\%) of the isolates with the type strains of recognized Arcobacter species. Hydrolysis of indoxyl acetate, a characteristic trait for all species of the genus Arcobacter, was negative for the novel isolates. The susceptibility of the novel isolates to cefoperazone, together with the lack of urease production and nitrate reduction, further enabled them to be differentiated from recognized Arcobacter species based on physiological characteristics. Genotypic and phenotypic characteristics indicated that the new isolates represent a novel species of the genus Arcobacter, for which the name Arcobacter mytili sp. nov. is proposed, with the type strain $\mathrm{F} 2075^{\top}\left(=\mathrm{CECT} 7386^{\top}=\mathrm{LMG} 24559^{\mathrm{T}}\right)$. The DNA G $+\mathrm{C}$ content of strain $\mathrm{F}_{2075^{\mathrm{T}}}$ was 26.9 mol\%.
\end{abstract}

In 1991, Vandamme and colleagues reclassified the 'aerotolerant campylobacters' in the genus Arcobacter, including Arcobacter nitrofigilis and Arcobacter cryaerophilus (Vandamme et al., 1991). The genus was emended a year later with the addition of Arcobacter butzleri and Arcobacter skirrowii (Vandamme et al., 1992). Two more novel species have since been described, Arcobacter cibarius, isolated from broiler carcasses in Belgium (Houf et al., 2005) and Arcobacter halophilus, isolated from a hypersaline lagoon in Hawaii (Donachie et al., 2005) and the genus currently comprises six species. Moreover, an autotrophic, obligate microaerophilic sulfide-oxidizing bacteria named 'Candidatus Arcobacter sulfidicus' of marine origin was

Abbreviations: ERIC-PCR, Enterobacterial repetitive intergenic consensus PCR; m-PCR, multiplex PCR.

The GenBank/EMBL/DDBJ accession numbers for the 16S rRNA gene and $r p o B$ sequences of strain $\mathrm{F}_{2075^{\top}}$ are EU669904 and EU669901, respectively.

Supplementary figures showing the ERIC-PCR patterns and a phylogenetic tree based on $r p o B$ gene sequences for species of the genus Arcobacter are available with the online version of this paper. described in 2002 as a possible additional novel taxon (Wirsen et al., 2002).

The type species of the genus, $A$. nitrofigilis, was first recovered from the roots of Spartina alterniflora, a salt marsh plant (McClung et al., 1983), and since then there have been few reports on this species (Figueras et al., 2008). A. butzleri is the most common species in environmental water, food and clinical samples (Ho et al., 2006). In fact, this species was ranked as the fourth most common campylobacterium isolated from human faeces in two independent studies performed in Belgium and France (Vandenberg et al., 2004; Prouzet-Mauléon et al., 2006). Recently, this species was considered to be a serious hazard to human health by the International Commission on Microbiological Specification for Foods (ICMSF, 2002). A. cryaerophilus, the second most commonly isolated species of the genus, has been recovered from cases of diarrhoea and bacteraemia in humans, as well as from the meat of several animals (Ho et al., 2006). This species was also recovered from faeces of $1.4 \%$ of healthy people (Houf \& Stephan, 2007). A. skirrowii is usually isolated from 
preputial fluids of bulls and faeces of animals, including sheep and cattle (Vandamme et al., 2005). It has also been associated with chronic diarrhoea in an old man (Wybo et al., 2004) and has been recently detected in humans with and without diarrhoea in South Africa (Samie et al., 2007). A. butzleri, A. cryaerophilus and A. skirrowii are frequently isolated from animal faeces (Van Driessche et al., 2003) and have recently been associated with faecally polluted environmental waters (Collado et al., 2008). Although the epidemiology of Arcobacter species is not clear, it has been suggested that water and foods are the transmission route of arcobacters to humans (Ho et al., 2006).

As part of a study on the prevalence of arcobacters in meat and shellfish products in Catalonia (north-east Spain), three isolates (F2026, F2075 ${ }^{\mathrm{T}}$ and F2076) were recovered from mussels (genus Mytilus) in 2006 and an additional strain (T234) was isolated from brackish water in 2008. Using a recently proposed Arcobacter species identification method, 16S rRNA gene RFLP, these isolates showed a specific pattern that was different from those defined for the six recognized species of the genus (Figueras et al., 2008). In the present study, a polyphasic approach was used to establish the taxonomic position of these novel isolates. For this purpose, phylogenetic analyses of the $16 \mathrm{~S}$ rRNA and $r p o B$ gene sequences, DNA-DNA hybridization experiments, DNA G $+\mathrm{C}$ content determination, enterobacterial repetitive intergenic consensus PCR (ERIC-PCR) genotyping and phenotypic analysis were performed. Based on the results obtained, we propose the allocation of these isolates to a novel species of the genus Arcobacter.

Mussel samples were taken from the Ebro river delta (north-east Spain) on 29 July (one sample) and 21 September 2006 (two samples) and were processed by homogenizing $10 \mathrm{~g}$ of mussel flesh with $90 \mathrm{ml}$ Arcobacter enrichment broth (Oxoid) supplemented with CAT comprising $\left(\mathrm{mg} \mathrm{l}^{-1}\right)$ cefoperazone (8), amphotericin B (10) and teicoplanin (4). After incubation for $48 \mathrm{~h}$ at $30{ }^{\circ} \mathrm{C}$ under aerobic conditions, $200 \mu \mathrm{l}$ broth was inoculated on a blood agar (BA) plate following the procedure described by Collado et al. (2008). Small, colourless or beige-to-offwhite, translucent colonies, the characteristic form of colonial growth for members of the genus Arcobacter, were selected from each sample for genetic identification. This was performed using a multiplex PCR (m-PCR) for simultaneous detection of A. butzleri, A. cryaerophilus and A. skirrowii (Houf et al., 2000) and a 16S rRNA gene RFLP method, which consists of an amplification of $1026 \mathrm{bp}$ of the 16S rRNA gene and posterior digestion with MseI endonuclease to obtain restriction patterns that enable characterization of the six recognized species (Figueras et al., 2008). Three mussel isolates, one recovered from the July sample (F2026) and one from each of the two September samples (F2075 ${ }^{\mathrm{T}}$ and F2076), were identified as A. skirrowii with the m-PCR method due to the presence of a $653 \mathrm{bp}$ band on the agarose gel that could not be differentiated from the $641 \mathrm{bp}$ band that is typical of $A$. skirrowii. However, the isolates showed a novel RFLP pattern $(650 / 143 / 138 \mathrm{bp})$ that did not correspond to any of the recognized Arcobacter species (Figueras et al., 2008). One additional isolate (T234) was recovered (June 2008) from brackish water (salinity $14.4 \%$ o) of the Ebro river delta using the isolation procedure described by Collado et al. (2008). This isolate was also identified as A. skirrowii with m-PCR and showed the same RFLP pattern as the mussel isolates.

To investigate the genetic relatedness of the four isolates, ERIC-PCR (Houf et al., 2002) was performed. Isolates $\mathrm{F} 2075^{\mathrm{T}}$ and F2076, despite having been isolated from different samples, were considered to have the same genotype on the basis of sharing the same ERIC-PCR pattern. This pattern was clearly different from those of isolates F2026 and T234 (see Supplementary Fig. S1, available in IJSEM Online).

The 16S rRNA genes of the four isolates (around $1460 \mathrm{bp}$ ) were amplified according to Martínez-Murcia et al. (1992) and sequenced in both directions using a BigDye Terminator v1.1 Cycle Sequencing kit (Applied Biosystems) with an ABI PRISM 3100 Genetic Analyzer (Applied Biosystems), according to the manufacturer's instructions. Sequence assembly was performed with AUTO ASSEMBLER (Applied Biosystems). In addition, the rpoB genes of the four novel isolates and 11 Arcobacter strains [two strains for each recognized species of the genus Arcobacter, with the exception of A. halophilus (see Supplementary Table S1)], were amplified using the PCR primers CamrpoB-L and RpoB-R and the conditions that have been established for use with the genus Campylobacter (Korczak et al., 2006). The expected PCR product size (524 bp) was obtained for all strains, with additional unexpected bands in some cases. The bands of the expected size were purified from the agarose gel with the GFX PCR DNA and Gel Band Purification kit (GE Healthcare) according to the manufacturer's instructions. The PCR products were sequenced in both directions and in duplicate. The $r p o B$ gene sequences were used to calculate the percentage nucleotide substitutions for a continuous stretch of $487 \mathrm{bp}$ (positions 1552-2039 according to Escherichia coli numbering).

Both sets of sequence data, for the 16S rRNA and rpoB genes, from strains $\mathrm{F} 2075^{\mathrm{T}}$ and F2076 were identical and confirmed the ERIC-PCR results. Therefore, strain F2076 was not subjected to further phylogenetic or phenotypic analysis.

Using sequences obtained from this study and from GenBank, separate alignments of $16 \mathrm{~S}$ rRNA gene sequences (1409 bp) and rpoB sequences (487 bp) were performed with CLUSTAL W (Thompson et al., 1994). Genetic distances were obtained using Kimura's two-parameter model (Kimura, 1980) and evolutionary trees were constructed by the neighbour-joining method with the MEGA4 program (Tamura et al., 2007). The stability of each relationship was assessed by bootstrap analysis (1000 replicates).

In both of the phylogenetic trees derived from the $16 \mathrm{~S}$ rRNA and $r p o B$ gene sequences (Fig. 1 and Supplementary 


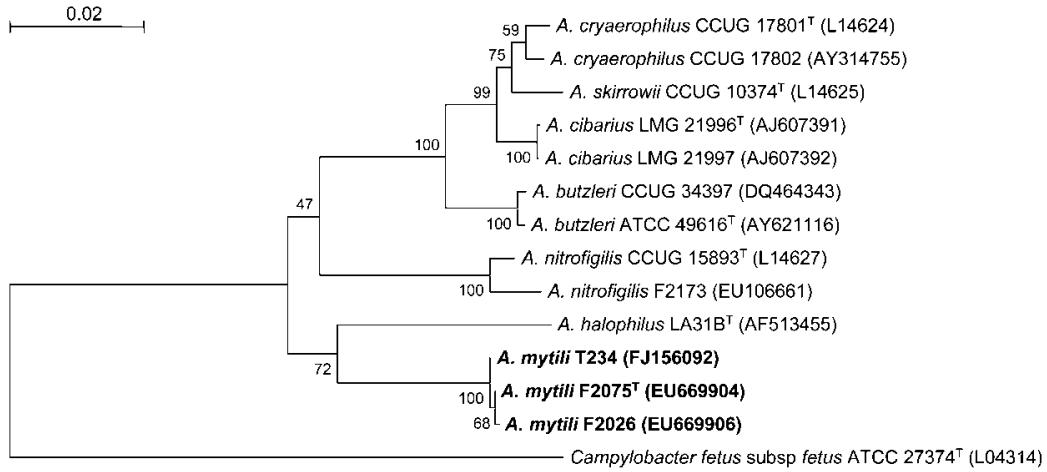

Fig. 1. Neighbour-joining phylogenetic tree showing the relationship of Arcobacter mytili sp. nov. with other Arcobacter species on the basis of 1409 nucleotides from the 16S rRNA gene. Numbers at nodes represent percentage bootstrap values (1000 replications). Bar, 2 substitutions per $100 \mathrm{nt}$.
Fig. S2), three of the novel strains (F2026, F2075 ${ }^{\mathrm{T}}$ and T234) formed a distinct clade with $A$. halophilus $\mathrm{LA} 31 \mathrm{~B}^{\mathrm{T}}$. The 16S rRNA gene sequence of strain $\mathrm{F} 2075^{\mathrm{T}}$ was compared with the sequences of type strains deposited in GenBank using both BLASTN (Altschul et al., 1990) and EZTAXON (Chun et al., 2007) and it showed the highest similarity values with the type strains of the six Arcobacter species: A. halophilus, $94.8 \%$; A. nitrofigilis, $93.8 \%$; A. butzleri, 93.6\%; A. cibarius, 93.3\%, A. cryaerophilus, $93.1 \%$, and A. skirrowii, $92.8 \%$. The levels of similarity to Campylobacter species were below $87.9 \%$. The $16 \mathrm{~S}$ rRNA gene sequence of strain $\mathrm{F} 2075^{\mathrm{T}}$ showed 99.9 and $99.8 \%$ sequence similarities with those of strains F2026 and T234, respectively. The $r p o B$ gene sequence similarities between strain $\mathrm{F} 2075^{\mathrm{T}}$ and each Arcobacter type strain were $88.0 \%, 86.7 \%, 85.8 \%, 83.0 \%, 82.1 \%$ and $81.9 \%$ for $A$. halophilus, A. butzleri, A. nitrofigilis, A. cryaerophilus, A. cibarius and $A$. skirrowii, respectively. The inter-species rate of nucleotide substitutions for the $r p o B$ gene was over $10.7 \%$, while the intra-species variation ranged from 0.2 to $5.3 \%$, with the sequences from A. skirrowii, A. butzleri and the novel isolates being at the lower range of intra-species variability (see Supplementary Fig. S2). In a recent study that analysed the relationship between $r p o B$ gene sequence similarity and DNA-DNA hybridization for 230 bacteria, a DNA-DNA relatedness value of more than $70 \%$ correlated with a $r p o B$ gene sequence similarity of $97.7 \%$, and this was proposed as the cut-off value for species delineation (Adékambi et al., 2008). The $r p o B$ gene sequence similarities between strain F2075 ${ }^{\mathrm{T}}$ and strains F2026 and T234 were 99.8 and $99.6 \%$, respectively, which are clearly above this cut-off value.

For DNA-DNA hybridization experiments and for the determination of DNA G + C content, genomic DNA was prepared according to the procedure of Wilson (1987) with the modification by Cleenwerck et al. (2002). DNA-DNA hybridizations were performed at $32{ }^{\circ} \mathrm{C}$ according to a modification (Goris et al., 1998; Cleenwerck et al., 2002) of the method described by Ezaki et al. (1989). Reciprocal reactions were performed for every comparison pair and the variation found was within the limits of this method (Goris et al., 1998). The DNA-DNA relatedness values reported are the means of a minimum of four hybridiza- tions. The DNA-DNA relatedness value obtained for strain $\mathrm{F} 2075^{\mathrm{T}}$ with $A$. halophilus $\mathrm{LA} 31 \mathrm{~B}^{\mathrm{T}}$, the most closely related species on the basis of the $16 \mathrm{~S}$ rRNA and $r p o B$ gene sequences, was $30 \%$, while values with all other recognized Arcobacter species were $23 \%$ or below (Table 1). Although these DNA-DNA hybridization values may seem low, they are not low in comparison with those recently published in the description of $A$. halophilus, which ranged between 4 and $12 \%$ with the other recognized Arcobacter species (Donachie et al., 2005). The G+C content of each DNA sample was determined by three independent analyses using the HPLC technique (Mesbah et al., 1989). The DNA $\mathrm{G}+\mathrm{C}$ content of strain $\mathrm{F} 2075^{\mathrm{T}}$ was $26.9 \mathrm{~mol} \%$, which is within the previously defined range of $26.8-35 \mathrm{~mol} \%$ for the genus (Donachie et al., 2005; Houf et al., 2005; Vandamme et al., 2005).

Phenotypic characterization of strains F2026, F2075 ${ }^{\mathrm{T}}$ and T234 was performed using the biochemical identification scheme of Vandamme et al. (2005) (Table 2). $\mathrm{NaCl}$ tolerance and susceptibility to cefoperazone were tested on nutrient broth no. 2 (Oxoid) supplemented with $5 \%$ whole sheep blood and $1.5 \%$ agar. The indoxyl acetate hydrolysis test was performed according to Mills \& Gherna (1987) and confirmed using indoxyl acetate diagnostic tablets (IAC)-DIETABS (Rosco Diagnostica). All tests were conducted at least twice. The novel isolates were biochemically different from the recognized species of the genus

Table 1. DNA-DNA relatedness between strain $\mathrm{F} 2075^{\top}$ and the type strains of other Arcobacter species

Results are expressed as the mean \pm standard deviation.

\begin{tabular}{|lc|}
\hline Strain & $\begin{array}{r}\text { DNA-DNA relatedness with strain } \\
\text { F2075 }^{\mathbf{T}} \text { (\%) }\end{array}$ \\
\hline A. halophilus LA31B ${ }^{\mathrm{T}}$ & $30 \pm 12$ \\
A. butzleri $\mathrm{LMG} 10828^{\mathrm{T}}$ & $23 \pm 1$ \\
A. skirrowii $\mathrm{LMG} 6621^{\mathrm{T}}$ & $19 \pm 8$ \\
A. nitrofigilis CECT $7204^{\mathrm{T}}$ & $16 \pm 2$ \\
A. cibarius CECT $7203^{\mathrm{T}}$ & $16 \pm 6$ \\
A. cryaerophilus $\mathrm{LMG} 9904^{\mathrm{T}}$ & $16 \pm 7$ \\
\hline
\end{tabular}


Table 2. Differential characteristics of Arcobacter mytili sp. nov. and other species of the genus Arcobacter

Species: 1, A. mytili sp. nov. ( $n=3$, data from this study); $2, A$. nitrofigilis ( $n=4$, this study); 3 , A. halophilus $(n=1) ; 4$, A. cibarius $(n=15) ; 5$, A. cryaerophilus ( $n=19$; four strains were retested in this study); 6, A. butzleri ( $n=12) ; 7$, A. skirrowii $(n=9)$. Data taken from previous studies (On et al., 1996; Donachie et al., 2005; Houf et al., 2005) unless otherwise indicated.,$+>95 \%$ Strains positive; ,$-<11 \%$ strains positive; $v, 12-94 \%$ strains positive.

\begin{tabular}{|lccccccc|}
\hline Characteristic & $\mathbf{1}$ & $\mathbf{2}$ & $\mathbf{3}$ & $\mathbf{4}$ & $\mathbf{5}$ & $\mathbf{6}$ & $\mathbf{7}$ \\
\hline Growth condition & & & & & & & \\
$\quad$ Air at $25{ }^{\circ} \mathrm{C}$ & + & + & + & $\mathrm{v}$ & + & + & + \\
MacConkey agar & + & - & - & + & $\mathrm{V}$ & + & - \\
Minimal media & - & - & - & + & $-{ }^{*}$ & + & - \\
NaCl $4 \%(\mathrm{w} / \mathrm{v})$ & + & + & + & - & - & - & + \\
Cefoperazone $\left(64 \mathrm{mg} \mathrm{l}^{-1}\right)$ & - & - & - & + & + & + & + \\
Enzyme activity & & & & & & & \\
$\quad$ Oxidase & + & + & + & + & + & + & + \\
Catalase & + & + & - & $\mathrm{v}$ & + & $\mathrm{v}$ & + \\
$\quad$ Urease & - & + & - & - & - & - & - \\
Nitrate reduction & - & + & + & - & $+\dagger$ & + & + \\
Indoxyl acetate hydrolysis & - & + & + & + & + & + & + \\
& & & & & & & \\
\hline
\end{tabular}

${ }^{\star}$ Two of the four strains tested in this study (LMG 7537 and LMG 10241) were positive.

$\dagger$ Two of the four strains tested in this study (LMG $9904^{\mathrm{T}}$ and LMG 9065) were negative.

Arcobacter in that they did not hydrolyse indoxyl acetate (Table 2). Since the studies of On et al. (1996) demonstrated that A. nitrofigilis was able to hydrolyse indoxyl acetate, which contradicted previous data (Mills \& Gherna, 1987), all species of the genus Arcobacter have been considered to be indoxyl-acetate-hydrolysis-positive. In the present study, using four strains of A. nitrofigilis (CECT $7204^{\mathrm{T}}$, LMG 7547, F2173 and F2176), the results of On et al. (1996) were corroborated as, despite the reactions being slower and weaker than that observed for the other species, they were clearly positive. The susceptibility to cefoperazone (64 $\mathrm{mg}^{-1}$ ) differentiated the novel isolates from $A$. butzleri, A. cibarius, A. cryaerophilus and A. skirrowii. The lack of urease activity enabled the novel strains to be differentiated from A. nitrofigilis. The growth in MacConkey agar and the inability to reduce nitrate to nitrite differentiated the novel strains from $A$. halophilus. In addition, strains F2026, F2075 ${ }^{\mathrm{T}}$ and T234 differed from the other Arcobacter speicies by their fast growth in BA (growth was observable after $24 \mathrm{~h}$ incubation in aerobic conditions).

Motility was observed in young cultures by examining wet mounts in nutrient broth no. 2 by phase-contrast microscopy. Cell size, morphology and presence of flagella (Fig. 2) were determined with transmission electron microscopy (JEOL 1011) after negative staining with $2 \%(\mathrm{w} / \mathrm{v})$ phosphotungstic acid solution ( $\mathrm{pH}$ 6.9) for $1 \mathrm{~min}$ and with scanning electron microscopy after fixing pieces of agar containing cells of
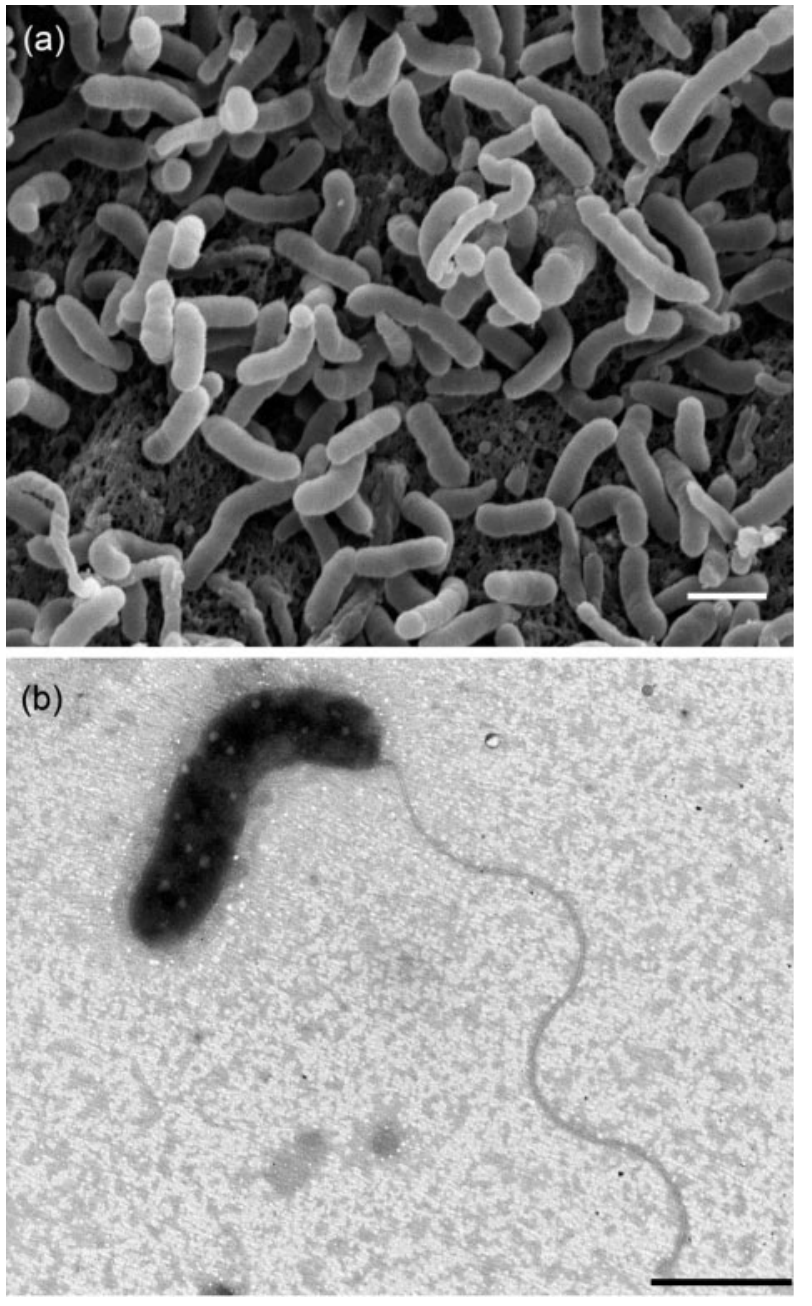

Fig. 2. Images of cells of strain $\mathrm{F} 2075^{\top}$ as observed with scanning electron microscopy (a) and transmission electron microscopy, negatively stained (b). Bars, $1 \mu \mathrm{m}$.

growing strain $\mathrm{F} 2075^{\mathrm{T}}$ in $2.5 \%$ glutaraldehyde in phosphate buffer for $24 \mathrm{~h}$. Subsequently, the samples were post-fixed in $1 \%$ osmium tetroxide for $2 \mathrm{~h}$. After dehydration and criticalpoint drying, specimens were mounted and coated with a thin layer of gold before examination with a JEOL JSM 6400 scanning electron microscope.

The data presented here support the suggestion that the four novel strains belong to a previously unrecognized species of the genus Arcobacter, for which the name Arcobacter mytili sp. nov. is proposed.

The recently described 16S rRNA gene RFLP Arcobacter identification protocol (Figueras et al., 2008) is currently the only fast method that enables the differentiation of these four novel strains from the rest of the species of the genus on the basis of specific restriction patterns. In contrast, the m-PCR method (Houf et al., 2000) misidentifies the four novel strains as A. skirrowii. 


\section{Description of Arcobacter mytili sp. nov.}

Arcobacter mytili (my'ti.li. L. gen. n. mytili of a mussel, from the genus name Mytilus, from which the species was first isolated).

Cells are Gram-negative, non-encapsulated, non-sporeforming, slightly curved rods, some S-shaped, 0.4-0.6 $\mu \mathrm{m}$ wide and 1-3 $\mu \mathrm{m}$ long. Motile by means of a single polar flagellum. Colonies on BA incubated in aerobic conditions at $30{ }^{\circ} \mathrm{C}$ for $48 \mathrm{~h}$ are $2-4 \mathrm{~mm}$ in diameter, beige to off-white, circular with entire margins, convex and non-swarming. Pigments are not produced. All strains grow on BA at room temperature $\left(18-22{ }^{\circ} \mathrm{C}\right)$ and at 30 and $37{ }^{\circ} \mathrm{C}$ under aerobic or microaerobic culture conditions with no significant differences. Under aerobic conditions, all strains grow at $30{ }^{\circ} \mathrm{C}$ on MacConkey agar and on media containing 2.0 $4.0 \%(\mathrm{w} / \mathrm{v}) \mathrm{NaCl}$. No growth is obtained on casein, minimal medium or media containing $64 \mathrm{mg}$ cefoperazone $\mathrm{l}^{-1}$. Weak growth is obtained in anaerobic conditions at $30{ }^{\circ} \mathrm{C}$ and in aerobic conditions at $42{ }^{\circ} \mathrm{C}$, and no growth is observed at $4{ }^{\circ} \mathrm{C}$. Oxidase-positive and weakly catalase-positive. Strains are not haemolytic and do not hydrolyse indoxyl acetate. Urease is not produced and nitrate is not reduced. Hydrogen sulfide is not produced in triple-sugar iron agar medium.

The type strain, $\mathrm{F} 2075^{\mathrm{T}}\left(=\mathrm{CECT} 7386^{\mathrm{T}}=\mathrm{LMG} 24559^{\mathrm{T}}\right)$, was isolated from mussels from Catalonia, Spain. The DNA $\mathrm{G}+\mathrm{C}$ content of the type strain is $26.9 \mathrm{~mol} \%$.

\section{Acknowledgements}

The BCCM/LMG bacteria collection is supported by the Prime Minister's Services-Federal Office for Scientific, Technical and Cultural Affairs, Belgium. We thank Laboratori de Salut Pública, Serveis Territorials de Salut de Tarragona for helpful collaboration and Dr Maqsudul Alam (University of Hawaii, Manoa, HI) and Dr Kurt Houf (Ghent University, Belgium) for kindly providing strains. This work was supported by funds from the European Commission for the HEALTHY WATER project (FOOD-CT-2006-036306). The authors are solely responsible for the content of this publication. It does not represent the opinion of the European Commission. The European Commission is not responsible for any use that might be made of data appearing therein.

\section{References}

Adékambi, T., Shinnick, T. M., Raoult, D. \& Drancourt, M. (2008). Complete $r p o B$ gene sequencing as a suitable supplement to DNADNA hybridization for bacterial species and genus delineation. Int $J$ Syst Evol Microbiol 58, 1807-1814.

Altschul, S. F., Gish, W., Miller, W., Myers, E. W. \& Lipman, D. J. (1990). Basic local alignment search tool. J Mol Biol 215, 403-410.

Chun, J., Lee, J. H., Jung, Y., Kim, M., Kim, S., Kim, B. K. \& Lim, Y. W. (2007). EzTaxon: a web-based tool for the identification of prokaryotes based on $16 \mathrm{~S}$ ribosomal RNA gene sequences. Int J Syst Evol Microbiol 57, 2259-2261.

Cleenwerck, I., Vandemeulebroecke, K., Janssens, D. \& Swings, J. (2002). Re-examination of the genus Acetobacter, with descriptions of Acetobacter cerevisiae sp. nov. and Acetobacter malorum sp. nov. Int $J$ Syst Evol Microbiol 52, 1551-1558.
Collado, L., Inza, I., Guarro, J. \& Figueras, M. J. (2008). Presence of Arcobacter spp. in environmental waters correlates with high levels of fecal pollution. Environ Microbiol 10, 1635-1640.

Donachie, S. P., Bowman, J. P., On, S. L. \& Alam, M. (2005). Arcobacter halophilus sp. nov., the first obligate halophile in the genus Arcobacter. Int J Syst Evol Microbiol 55, 1271-1277.

Ezaki, T., Hashimoto, Y. \& Yabuuchi, E. (1989). Fluorometric deoxyribonucleic acid-deoxyribonucleic acid hybridization in microdilution wells as an alternative to membrane filter hybridization in which radioisotopes are used to determine genetic relatedness among bacterial strains. Int J Syst Bacteriol 39, 224-229.

Figueras, M. J., Collado, L. \& Guarro, J. (2008). A new 16S rDNARFLP method for the discrimination of the accepted species of Arcobacter. Diagn Microbiol Infect Dis 62, 11-15.

Goris, J., Suzuki, K., De Vos, P., Nakase, T. \& Kersters, K. (1998). Evaluation of a microplate DNA-DNA hybridization method compared with the initial renaturation method. Can J Microbiol 44, 1148-1153.

Ho, H. T. K., Lipman, L. J. \& Gaastra, W. (2006). Arcobacter, what is known about a potential foodborne zoonotic agent! Vet Microbiol $115,1-13$.

Houf, K. \& Stephan, R. (2007). Isolation and characterization of the emerging foodborn pathogen Arcobacter from human stool. $J$ Microbiol Methods 68, 408-413.

Houf, K., Tutenel, A., De Zutter, L., Van Hoof, J. \& Vandamme, P. (2000). Development of a multiplex PCR assay for the simultaneous detection and identification of Arcobacter butzleri, Arcobacter cryaerophilus and Arcobacter skirrowii. FEMS Microbiol Lett 193, 8994.

Houf, K., De Zutter, L., Van Hoof, J. \& Vandamme, P. (2002). Assessment of the genetic diversity among arcobacters isolated from poultry products by using two PCR-based typing methods. Appl Environ Microbiol 68, 2172-2178.

Houf, K., Stephen, L., On, W., Coenye, T., Mast, J., Van Hoof, J. \& Vandamme, P. (2005). Arcobacter cibarius sp. nov., isolated from broiler carcasses. Int J Syst Evol Microbiol 55, 713-717.

ICMSF (2002). Microorganisms in Foods 7 - Microbiological Testing in Food Safety Management. International Commission on Microbiological Specifications for Foods. New York: Kluwer Academic/Plenum.

Kimura, M. (1980). A simple method for estimating evolutionary rates of base substitutions through comparative studies of nucleotide sequences. J Mol Evol 16, 111-120.

Korczak, B. M., Stieber, R., Emler, S., Burnens, A. P., Frey, J. \& Kuhnert, P. (2006). Genetic relatedness within the genus Campylobacter inferred from rpoB sequences. Int J Syst Evol Microbiol 56, 937-945.

Martínez-Murcia, A. J., Benlloch, S. \& Collins, M. D. (1992). Phylogenetic interrelationships of members of the genera Aeromonas and Plesiomonas as determined by $16 \mathrm{~S}$ ribosomal DNA sequencing: lack of congruence with results of DNA-DNA hybridizations. Int J Syst Bacteriol 42, 412-421.

McClung, C. R., Patriquin, D. G. \& Davis, R. E. (1983). Campylobacter nitrofigilis sp. nov., a nitrogen-fixing bacterium associated with roots of Spartina alterniflora Loisel. Int J Syst Bacteriol 33, 605-612.

Mesbah, M., Premachandran, U. \& Whitman, W. B. (1989). Precise measurement of the $\mathrm{G}+\mathrm{C}$ content of deoxyribonucleic acid by high-performance liquid chromatography. Int J Syst Bacteriol 39, 159167.

Mills, C. K. \& Gherna, R. L. (1987). Hydrolysis of indoxyl acetate by Campylobacter species. J Clin Microbiol 25, 1560-1561. 
On, S. L., Holmes, B. \& Sackin, M. J. (1996). A probability matrix for the identification of campylobacters, helicobacters and allied taxa. J Appl Bacteriol 81, 425-432.

Prouzet-Mauléon, V., Labadi, L., Bouges, N., Menard, A. \& Megraud, F. (2006). Arcobacter butzleri: underestimated enteropathogen. Emerg Infect Dis 12, 307-309.

Samie, A., Obi, C. L., Barrett, L. J., Powell, S. M. \& Guerrant, R. L. (2007). Prevalence of Campylobacter species, Helicobacter pylori and Arcobacter species in stool samples from the Venda region, Limpopo, South Africa: Studies using molecular diagnostic methods. J Infect 54, $558-566$.

Tamura, K., Dudley, J., Nei, M. \& Kumar, S. (2007). MEGA4: molecular evolutionary genetics analysis (MEGA) software version 4.0. Mol Biol Evol 24, 1596-1599.

Thompson, J. D., Higgins, D. G. \& Gibson, T. J. (1994). CLUSTAL W: improving the sensitivity of progressive multiple sequence alignment through sequence weighting, position-specific gap penalties and weight matrix choice. Nucleic Acids Res 22, 4673-4680.

Vandamme, P., Falsen, E., Rossau, R., Hoste, B., Segers, P., Tytgat, R. \& De Ley, J. (1991). Revision of Campylobacter, Helicobacter and Wolinella taxonomy: emendation of generic descriptions and proposal of Arcobacter gen. nov. Int J Syst Bacteriol 41, 88-103.

Vandamme, P., Vancanneyt, M., Pot, B., Mels, L., Hoste, B., Dewettinck, D., Vlaes, L., van den Borre, C., Higgins, R. \& other authors (1992). Polyphasic taxonomic study of the emended genus Arcobacter with Arcobacter butzleri comb. nov. and Arcobacter skirrowii sp. nov., an aerotolerant bacterium isolated from veterinary specimens. Int J Syst Bacteriol 42, 344-356.

Vandamme, P., Dewhirst, F. E., Paster, B. J. \& On, S. L. W. (2005). Genus II. Arcobacter Vandamme, Falsen, Rossau, Segers, Tytgat and De Ley 1991a, 99 ${ }^{\mathrm{VP}}$. In Bergey's Manual of Systematic Bacteriology, 2nd edn, vol. 2, pp. 1161-1165. Edited by D. J. Brenner, N. P. Kreig, J. T. Staley \& G. M. Garrity. New York: Springer.

Vandenberg, O., Dediste, A., Houf, K., Ibekwem, S., Souayah, H., Cadranel, S., Douat, N., Zissis, G., Butzler, J. P. \& Vandamme, P. (2004). Arcobacter species in humans. Emerg Infect Dis 10, 1863-1867.

Van Driessche, E., Houf, K., Van Hoof, J., De Zutter, L. \& Vandamme, P. (2003). Isolation of Arcobacter species from animal feces. FEMS Microbiol Lett 229, 243-248.

Wilson, K. (1987). Preparation of genomic DNA from bacteria. In Current Protocols in Molecular Biology, pp. 241-245. Edited by F. M. Ausubel, R. Brent, R. E. Kingston, D. D. Moore, J. G. Seidman, J. A. Smith \& K. Struhl. New York: Greene Publishing and Wiley Interscience.

Wirsen, C. O., Sievert, S. M., Cavanaugh, C. M., Molyneaux, S. J., Ahmad, A., Taylor, L. T., DeLong, E. F. \& Taylor, C. D. (2002). Characterization of an autotrophic sulfide-oxidizing marine Arcobacter sp. that produces filamentous sulfur. Appl Environ Microbiol 68, 316-325.

Wybo, I., Breynaert, J., Lauwers, S., Lindenburg, F. \& Houf, K. (2004). Isolation of Arcobacter skirrowii from a patient with chronic diarrhea. J Clin Microbiol 42, 1851-1852. 